\title{
Instrument Speed Endurance Test of Pencak Silat Athletes
}

\author{
Suwirman $^{1}$, Sepriadi ${ }^{1,2,}$, Nurul Ihsan ${ }^{1}$, Deswandi $^{1}$ \\ ${ }^{1}$ Sport Education Study Program, Universitas Negeri Padang, 25133, Padang, West Sumatera, Indonesia \\ ${ }^{2}$ Doctoral Program of Sport Science, Universitas Negeri Padang, 25133, Padang, West Sumatera, Indonesia
}

Received July 28, 2021; Revised November 8, 2021; Accepted November 22, 2021

\begin{abstract}
Cite This Paper in the following Citation Styles
(a): [1] Suwirman, Sepriadi, Nurul Ihsan, Deswandi , "Instrument Speed Endurance Test of Pencak Silat Athletes," International Journal of Human Movement and Sports Sciences, Vol. 9, No. 6, pp. 1447 - 1452, 2021. DOI: 10.13189/saj.2021.090641.
\end{abstract}

(b): Suwirman, Sepriadi, Nurul Ihsan, Deswandi (2021). Instrument Speed Endurance Test of Pencak Silat Athletes. International Journal of Human Movement and Sports Sciences, 9(6), 1447 - 1452. DOI: 10.13189/saj.2021.090641.

Copyright $\bigcirc 2021$ by authors, all rights reserved. Authors agree that this article remains permanently open access under the terms of the Creative Commons Attribution License 4.0 International License

\begin{abstract}
Pencak silat is a branch of martial arts that really requires good physical condition to be able to achieve maximum performance. One of the most needed physical conditions is speed endurance. However, at this time, there is no instrument to measure speed endurance specifically for the branch of pencak silat. In pencak silat matches, the dominant technique used by fighters to carry out attacks and get value is kicks. Therefore, in the implementation of this designed test, the kick technique is used. The target to be achieved in this study is the birth of a standard instrument to measure the speed endurance of pencak silat athletes. This research is a development research that aims to develop a special speed endurance instrument for athletes in pencak silat. The stages of this study began with an analysis of the needs of the physical condition in pencak silat. After that, the next stage is carried out, namely the making of speed endurance instrument designs for pencak silat athletes. Before conducting field trials, expert validation is first carried out by involving experts in the field of pencak silat, namely pencak silat trainers, sports test and measurement experts, and sports physiology experts. Field trials were carried out by direct testing of the research sample involving 100 male and 60 female pencak silat athletes. This trial is to determine the validity and reliability of field data and to determine test norms. The data analysis technique was done by using the percentage technique. The results showed that: the instrument of speed endurance developed is suitable for use as a measure of the speed endurance of pencak silat athletes with a validity of 0.95 and a reliability of 0.97 .
\end{abstract}

Keywords Endurance, Pencak Silat, Speed

\section{Introduction}

Pencak Silat is a sport that has complex movements and physical conditions. This is because a pencak silat athlete is required to have speed, endurance, strength and flexibility which are basic physical components, but athletes must also have a higher level of basic physical conditions including a combination of speed and strength, endurance, and speed [1],[2]. One of the elements of the physical condition that is needed in pencak silat is speed endurance.

Pencak silat has movements in attack, parry, and dodge. One type of attack that athletes often use in pencak silat matches is kicks. Based on several studies conducted, more than $75 \%$ of the attacks used in pencak silat matches are attacks using kick techniques. In every pencak silat match, it can be said that all fighters use this technique with its various variations to seek victory [3],[4],[5]. This attack must be carried out quickly so that it is difficult for the opponent to anticipate and this speed must be maintained at each round during the match. The required physical condition is called speed endurance.

Pencak silat is one of the branches of martial arts that uses a lot of leg muscle work in carrying out attacks, especially when kicking. So, because of the continuous kicking movement that is done quickly, one of the 
elements needed in Pencak silat is speed endurance.

Speed endurance is a combination of speed and endurance work capabilities. Furthermore, explains that the higher endurance in the physical component is anaerobic resistance [6],[7]. Therefore for the martial arts branch, the athlete's speed endurance must have good endurance and speed. In order to have good speed endurance, the training must be done at a high level in the sense of training with a very high intensity. Speed endurance must be maintained for a relatively long duration [8].

At this time many pencak silat trainers have carried out and provided speed endurance training programs to their athletes. However, instruments to measure whether there is an increase in speed endurance for pencak silat athletes still exists. So, the coaches have not been able to know the results of the exercises program that have been done.

A good measuring instrument is a tool that is easy to use and can measure what you want to measure. This is in accordance with Djaali which explains that a measurement instrument is said to be valid if it can measure what you want to measure [9]. Furthermore, Sumadi explains that the instrument will determine the quality of the data collected and also the quality of the research [10].

Pencak silat competition rules consist of 3 rounds, where each round lasts 2 minutes (excluding stoppage time by the referee) and between rounds there is a 1 minute rest period. For 2 minutes in each round, a pencak silat athlete must be able to carry out attacks with good quality repeatedly. This is because, the attack that is judged is a powerful attack, fast, on target, with a perfect stance, the right trajectory, without being hindered by the opponent's body part. Based on this, it can be seen that the attacks that generate value are fast, strong and targeted attacks. The quality of this attack must be able to be done repeatedly for. This means that the attack carried out must have an element of speed endurance which is also combined with other elements of physical condition during the match.

In between rounds of matches are given a break of 1 minute. If you pay attention to this 1 minute rest period, it is certainly not sufficient for athletes to fully recover from fatigue during an attack. So with this condition it can be seen that speed endurance is really needed in pencak silat.

A good coach must be able to use the measurement process with valid instruments to determine the athlete's ability. This is because the coach is not only in charge of training but also has to know the data and the needs of the athletes. To measure and collect data, a valid and reliable measuring instrument is needed. The measurement result data are needed by a trainer as a basis for evaluating the results of the exercise.

In addition, based on observations and discussions with the pencak silat trainer, it was found that there is no means of measuring speed endurance for pencak silat athletes. So that we need a measuring instrument to measure the speed endurance of pencak silat athletes that can be used by pencak silat trainers and also other researchers in an effort to achieve maximum performance.

\section{Methods}

This research was a development research [11], [12], [13]. This research is a development research that aims to develop a special speed endurance instrument for athletes in the martial arts branch In this research, the development procedure was modified according to the constraints and conditions, including: (1) Preliminary Study (2) Needs Analysis, (3) Initial Product Design, (4) Validity, (5) Revision, (6) Trial, (7) Reliability, (8) Valid and Reliable Exercise Model.

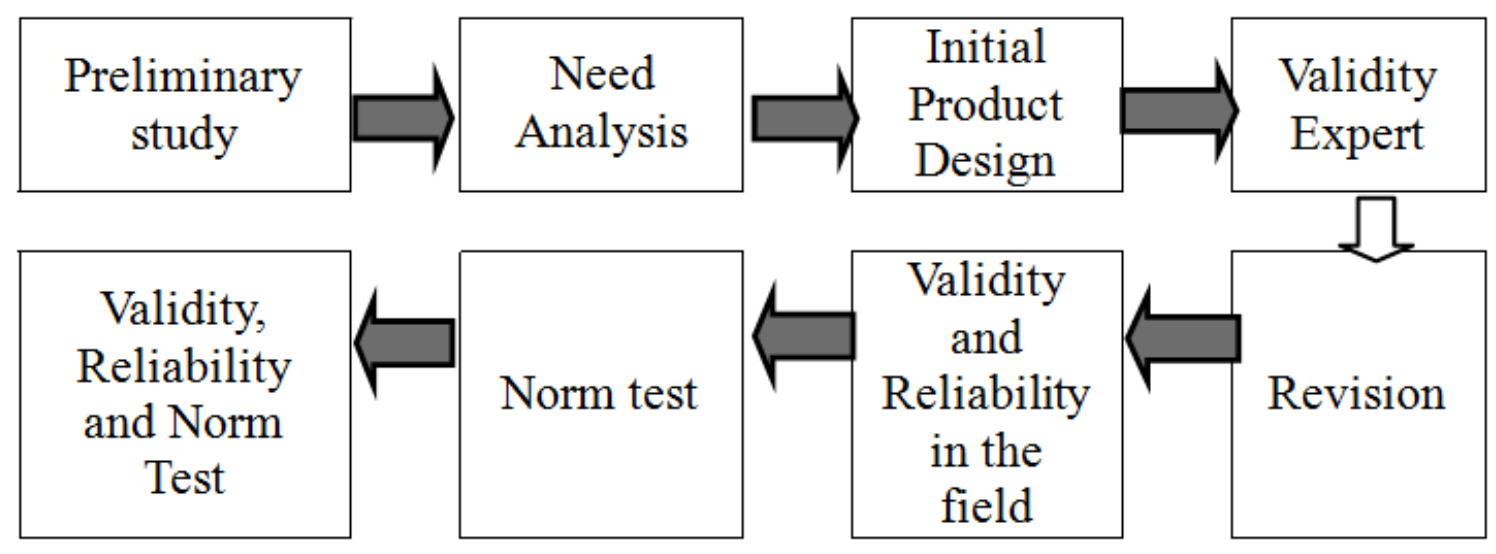

Figure 1. Research and Development Steps 
The stages in this preliminary study began with an analysis of the physical condition requirements in the branch of pencak silat. After finding that one of the most important things is speed endurance, the next step is to make a speed endurance instrument design for pencak silat athletes. So that we get a test as an instrument of speed endurance in the branch of pencak silat. After that, expert validation is carried out before field trials are carried out by involving experts in the field of pencak silat, namely pencak silat trainers, sports test and measurement experts, and sports physiology experts. Field trials were carried out by direct testing of the research sample involving 100 male and 60 female pencak silat athletes. This trial is to determine the validity and reliability of field data and to determine test norms. The data analysis technique is done by using the percentage technique.

\section{Results}

Based on the results of the instrument design as well as the validation of the pencak silat coach, sports test and measurement expert, and sports physiologist, the expert validation results showed a value of $86.07 \%$ which is classified as very feasible and valid to measure the speed endurance of pencak silat athletes. In addition, a field test was also carried out which showed that the speed endurance instrument for pencak silat athletes was very valid and reliable as a measuring tool for the speed endurance of pencak silat athletes with a validity level with a value of $r=0.955$ and reliability with a value of $r=$ 0.977. Then, the MET TEST is obtained as a speed endurance test instrument for pencak silat athletes.

\section{MET TEST (Speed Endurance Test Instrument of Pencak Silat Athletes)}

\section{Purpose: To measure the speed endurance of pencak silat athletes}

Tools and materials:

1) Medium size Paching Pad

2) Stopwatch

3) Test form

4) Stationery

Implementation:
1. One assistant holds the paching pad, and the testee stands in tide position one kick away from the paching pad holder.

2. When the start of the test has sounded, then the testee kicks the right $(\mathrm{ka})$ and left (ki) sickles alternately for 10 seconds.

3. After 10 seconds, a signal is sounded again to signal the testee to stop kicking. This means that the testee has finished doing the test at level 1 set 1 .

4. Then the testee is given a rest period between sets for 30 seconds.

5. After that, the testee returns to the starting position and is ready to enter level 1 set 2 , which is to do 1 right and 1 left sickle kick consecutively for 10 seconds.

6. Then the testee is given a break between levels for 60 seconds. And testees are ready to enter the next level.

7. Testee enters level 2 set 1 by doing sickle kick twice right leg and left leg twice in a row (2 right and 2 left) for 10 seconds, then rest 30 seconds.

8. Testee enters level 2 set 2 by taking 2 more right and 2 left kicks for 10 seconds, the whistle is sounded and the testee stops kicking and rest for 60 seconds.

9. Testee enters level 3 set 1 by taking 3 right and 3 left kicks for 10 seconds, then resting 30 seconds.

10. Testee takes 3 sets of level 3 sickle kicks and rest for 60 seconds

11. Testee performs kick repetitions as many as the level entered, meaning that if you enter level 4 then the testee kicks the right foot 4 times and the left foot 4 times continuously for 10 seconds. And if the testee reaches level 10 it means that the testee kicks 10 right and 10 left.

12. Levels and sets can be seen in test form.

13. Rest between sets for 30 seconds and rest between levels for 60 seconds.

14. The test will be stopped if the testee is unable to kick less than 20 times in each set.

Rating:

The number of levels and sets that can be performed by testee is recorded as test results and converted into assessments to determine the prediction of the speed endurance ability of pencak silat athletes as in table 2 . The assessment of this test can use the Instruments Test Speed Endurance form as shown in table 1. 
Table 1. MET TEST FORM

(Instruments Test Speed Endurance of Pencak Silat Athletes)

Name:

Gender:

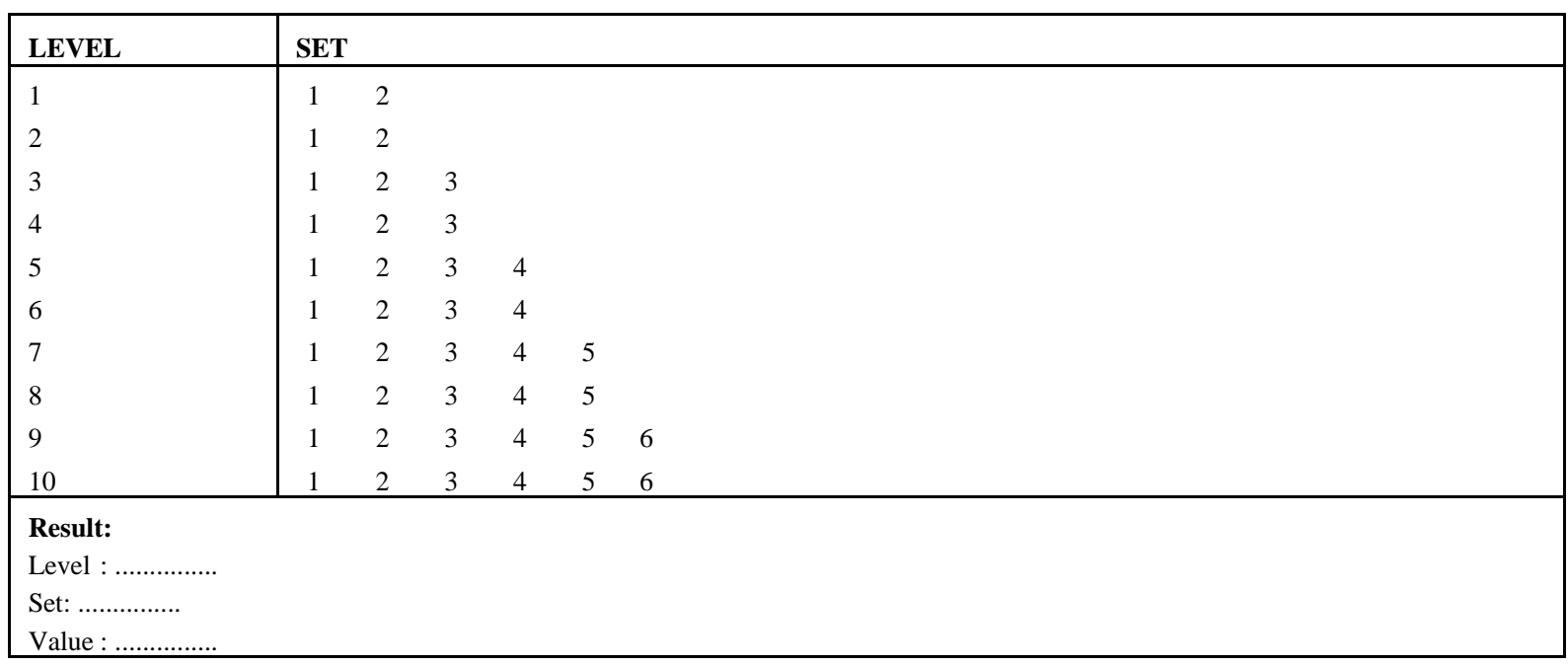

Table 2. Assessment of the speed endurance test of Pencak Silat athletes

\begin{tabular}{|c|c|c|}
\hline LEVEL & SET & SCORE \\
\hline 1 & 1 & 22 \\
\hline 1 & 2 & 24 \\
\hline
\end{tabular}

\begin{tabular}{|l|l|l|}
\hline 2 & 1 & 26 \\
\hline 2 & 2 & 28 \\
\hline
\end{tabular}

\begin{tabular}{|c|c|c|}
\hline LEVEL & SET & SCORE \\
\hline 7 & 1 & 58 \\
\hline 7 & 2 & 60 \\
\hline 7 & 3 & 62 \\
\hline 7 & 4 & 64 \\
\hline 7 & 5 & 66 \\
\hline
\end{tabular}

\begin{tabular}{|l|l|l|}
\hline 3 & 1 & 30 \\
\hline 3 & 2 & 32 \\
\hline 3 & 3 & 34 \\
\hline
\end{tabular}

\begin{tabular}{|l|l|l|}
\hline 4 & 1 & 36 \\
\hline 4 & 2 & 38 \\
\hline 4 & 3 & 40 \\
\hline
\end{tabular}

\begin{tabular}{|l|l|l|}
\hline 8 & 1 & 68 \\
\hline 8 & 2 & 70 \\
\hline 8 & 3 & 72 \\
\hline 8 & 4 & 74 \\
\hline 8 & 5 & 76 \\
\hline
\end{tabular}

\begin{tabular}{|l|l|l|}
\hline 5 & 1 & 42 \\
\hline 5 & 2 & 44 \\
\hline 5 & 3 & 46 \\
\hline 5 & 4 & 48 \\
\hline
\end{tabular}

\begin{tabular}{|l|l|l|}
\hline 9 & 1 & 78 \\
\hline 9 & 2 & 80 \\
\hline 9 & 3 & 82 \\
\hline 9 & 4 & 84 \\
\hline 9 & 5 & 86 \\
\hline 9 & 6 & 88 \\
\hline
\end{tabular}

\begin{tabular}{|l|l|l|}
\hline 6 & 1 & 50 \\
\hline 6 & 2 & 52 \\
\hline 6 & 3 & 54 \\
\hline 6 & 4 & 56 \\
\hline
\end{tabular}

\begin{tabular}{|c|c|c|}
\hline 10 & 1 & 90 \\
\hline 10 & 2 & 92 \\
\hline 10 & 3 & 94 \\
\hline 10 & 4 & 96 \\
\hline 10 & 5 & 98 \\
\hline 10 & 6 & 100 \\
\hline
\end{tabular}




\section{Discussion}

Physical condition is one of components needed more attention from coaches or athletes as a basic to improvement of athlete's ability. In many sports, endurance and speed are essential physical components. Endurance is a person's ability to carry out activities or hold weights for a long time. According to it is explained that endurance is the ability to implement the heart, respiratory and circulatory systems effectively and efficiently in continuous activities for a relatively long time by using the energy system [14], [15]. So endurance is the ability to maintain a load during work for a long time.

Speed does not only mean moving the whole body quickly, but can also be limited to moving the limbs in the shortest time as stated by speed is the ability to make movements or cover a distance with in short time [16]. Furthermore Harman \& Garhammer define velocity as the short time it takes for an object to move along a fixed distance, which is the same as the velocity, but without specifying the direction [17]. In practical terms, it refers to the ability to move the body as quickly as possible over a certain distance. So, speed is the ability to perform similar movements in succession in the shortest possible time, or the ability to cover a distance in the shortest possible time.

In pencak silat also requires endurance. When viewed from the need for physical components in the sport of pencak silat during a match, a pencak silat athlete must have endurance, especially speed endurance because he can carry out strong attacks quickly. The need for speed endurance is because attack movements, especially kicks, must be done repeatedly during the match.

Speed endurance is a combination of endurance and speed. Speed endurance is anaerobic resistance. According to Sukadiyanto anaerobic, endurance is the ability to rapidly develop the heart, respiratory and circulatory systems in a short time using the ATP-PC energy system [14].

The pencak silat match lasts for 3 rounds, where each round has 2 minutes of fighting time. This means that a pencak silat athlete must be able to perform strong and fast movements for 2 minutes without any significant rest time. The rest time between rounds of matches is 1 minute. This means that with a time of 1 minute, it still does not provide enough time to recover from fatigue when competing. A fighter for 2 minutes must have good endurance skills, and must also have fast attack abilities during the match. This means that a fighter must be able to carry out attacks that have elements of strength and speed during the match. If the speed endurance of a pencak silat athlete in kicking is not good, it will be easy for the opponent to retaliate or attack. So that a pencak silat athlete is no longer able to carry out fast attacks when competing.

In adittion, MET Test can be used in terms of measuring the speed endurance of pencak silat athletes because at this time an instrument specifically measuring speed endurance, especially in kicking for pencak silat athletes has not yet been developed. Based on the measurement results of the Pencak Silat College Athletes in West Sumatra, the Norms of the Pencak Silat Speed Endurance Test are obtained. This norm is obtained using a 5A scale with the following formula:

Table 3. Scale 5A [13]

\begin{tabular}{|c|c|}
\hline Category & Scale Limit \\
\hline Very Good & $\geq$ Mean $+(1,50 x S D)$ \\
\hline Good & Mean $+(0,50 x S D)$ \\
\hline Enough & Mean $-(0,50 x S D)$ \\
\hline Less & Mean $-(1,50 x S D)$ \\
\hline Very less & $\leq$ Mean $-(1,51 x S D)$ \\
\hline
\end{tabular}

Based on the analysis of the measurement results the speed endurance of Pencak Silat athletes in West Sumatera using an instrument that the research team has compiled, the norms of the Pencak Silat Speed Endurance Test (MET Test) are as follows:

Table 4. MET Test Norms for Male

\begin{tabular}{|c|c|}
\hline Category & Score \\
\hline Very Good & $\geq 73$ \\
\hline Good & $57-72$ \\
\hline Enough & $41-56$ \\
\hline Less & $25-40$ \\
\hline Very Less & $\leq 24$ \\
\hline
\end{tabular}

Table 5. MET Test Norms for Women

\begin{tabular}{|c|c|}
\hline Category & Score \\
\hline Very Good & $\geq 67$ \\
\hline Good & $53-66$ \\
\hline Enough & $39-52$ \\
\hline Less & $25-38$ \\
\hline Very Less & $\leq 24$ \\
\hline
\end{tabular}

\section{Conclusions}

The results and discussion that have been described shows a conclusion that MET test valid and reliable for measuring of speed endurance pencak silat athletes. MET test also shows more objective measurement results especially in kicking for pencak silat athletes.

\section{REFERENCES}


[1] Sepriadi, "The Contribution Of Fatique Index And Hemoglobin Levels On Physical Fitness,” Int. J. Sci. Technol. Res., vol. 9, no. 2, pp. 2894-2899, 2020.

[2] Sepriadi, K. Jannah, and Eldawaty, "The effect of jogging exercise to improve hemoglobin levels,” J. Phys. Conf. Ser., vol. 1481, p. 12028, 2020, doi:10.1088/1742-6596/1481/1/ 012028.

[3] R.Ketot Riadi, Teknik DasarPencak Silat Tanding. Jakarta: PT. Dian Rakyat, 2003.

[4] S. Ihsan, N., \& Suwirman, "Sumbangan Konsentrasi terhadap Kecepatan Tendangan Pencak Silat," Media Ilmu Keolahragaan Indones., vol. 8, no. 1, pp. 1-6, 2018.

[5] N. Sin, T. H., \& Ihsan, "The effectiveness of Pencak Silat to change teenage personalities,” J. Konseling dan Pendidik., vol. 8, no. 1, pp. 1-8, 2020.

[6] Harsono, Kepelatihan Olahraga Teori dan Metodologi. Bandung: PT. Remaja Rosdakarya, 2016.

[7] S. Sepriadi, "Kontribusi Power Otot Tungkai dan Keseimbangan terhadap Tendangan Mawashi Geri Atlit Kempo,” Media Ilmu Keolahragaan Indones., vol. 8, no. 2, pp. 31-39, 2018, doi: https://doi.org/10.15294/miki.v8i2.1 4986.

[8] D. Z. Sidik, Mengajar dan Melatih Atletik. Bandung: PT.
Remaja Rosdakarya, 2011.

[9] Djaali \& Pudji Muljono, Pengukuran dalam Bidang Pendidikan. Jakarta: PT Grasindo.

[10] S. Sumadi, Psikologi Pendidikan. Jakarta: Raja Grafindo Persada, 2013.

[11] M.. Borg, Walter R. \& Gall, Educational Research: An Introduction, 7th ed. New York \& London: Longman, 2003.

[12] Bennett. N.. Borg. W. R.. \& Gall. M. D., "Educational Research: An Introduction,” J. Educ. Stud., vol. 32, no. 3, 1984, doi: https://doi.org/10.2307/3121583\.

[13] Sugiyono, Metode penelitian kuantitatif, kualitatif dan $R \& D$. Jakarta: Alfabeta, 2011.

[14] Sukadiyanto, Pengantar Teori dan Metodologi Melatih Fisik. Yogyakarta: CV. Lubuk Agung, 2011.

[15] Agus, Apri \& Sepriadi, Manajemen Kebugaran. Padang: CV. Sukabina Press, 2018.

[16] C. B. R. L. Corbin, Fitnes For Life. United States of America Human Kinetics, 2007.

[17] J. Harman,E., \& Garhammer, Administration, Scoring, and Interpretation of Selected Tests. In: Essentials of Strength Training and Conditioning, 3rd ed. Human Kinetics, 2008. 